\title{
SYSTEMIC
}

Vol. 03, No. 01, Agustus 2017, 9-14

\section{Desain Prototype Sistem Informasi Hafalan Al Quran Berbasis Perspektif HCI}

\author{
Dwi Rolliawati), Laily Nur Qomary ${ }^{2)}$, Aslichatul Millah ${ }^{3)}$ \\ State Islamic University of Sunan Ampel Surabaya \\ ${ }^{1}$ dwi_roll@uinsby.ac.id, ${ }^{2}$ lailynurqomary@gmail.com, ${ }^{3}$ azzaalmillah@gmail.com
}

\begin{abstract}
Penelitian ini bertujuan untuk mengembangkan produk prototipe berbasis IT yang bisa mempermudah dan meningkatkan produktivitas proses bisnis yang ada di UPTQ (Unit Pengembangan Tahfidzul Quran) berupa sistem informasi hafalan Al-Quran dengan perspektif HCI (Human Computer Interaction). Metode penelitian menggunakan Research and Developmen (R\&D) level 1 dengan metode pengembangan perangkat lunak berbasis prototipe. Pengembangan prototipe Sistem Informasi Hafalan Al-Quran diuji melalui 2 (dua) metode, metode Heuristic Evaluation untuk pengujian desain interface dan ISO 9241-1 untuk pengujian aspek usability. Hasil pengujian tingkat efektifitas dari sistem "Baik" yaitu sebesar 82,1\%. Hasil pengujian tingkat efisiensi tergolong "Baik" yaitu sebesar $81,87 \%$ dan tingkat kepuasan terhadap sistem "Cukup Baik" yaitu sebesar 78,9\%. Diperoleh hasil uji kelayakan aspek usability dari sistem sebesar $80,22 \%$ dan dinyatakan layak untuk digunakan/diimplementasikan di UPTQ UIN Sunan Ampel Surabaya.
\end{abstract}

Keywords: HCI, Heuristic Evaluation, usability, ISO 9241-1, UPTQ

\section{PENDAHULUAN}

HCI (Human Computer Interaction) telah umum dibicarakan, membahas interaksi antara komputer dengan manusia, sebagai pengembang atau pengguna, sebagai individu atau kelompok [1], [2]. HCI mengacu pada banyak disiplin ilmu, namun dalam sains dan desain sistem komputer, hal itu harus diterima sebagai perhatian utama. Untuk semua disiplin ilmu lainnya, HCI bisa menjadi spesialisasi, memberi masukan penting untuk desain sistem, yang merupakan bagian penting dari proses perancangan. Dari perspektif ini, HCI melibatkan perancangan, implementasi dan evaluasi sistem interaktif dalam konteks tugas dan pekerjaan pengguna [2].

Desain user interface sangat penting untuk keberhasilan implementasi sistem informasi. Desain yang baik mulai dengan pemahaman tentang psycologhy dan teknologi [3]. Proyek Teknologi Informasi menginvestasikan sejumlah besar sumber daya dalam perancangan dan konstruksi antarmuka pengguna, dalam beberapa kasus $80-90 \%$ kode sistem melibatkan elemen antarmuka pengguna. Jika antarmuka pengguna dirancang dengan buruk, keefektifan dan efisiensi pengguna akan menurun, mengurangi keuntungan produktivitas yang dibayangkan untuk sistem. Oleh karena itu penting untuk memahami dampaknya pada pengguna pada berbagai desain antarmuka pengguna [1][4]. Mengapa penelitian ini dilakukan? Karena tingkat ketertarikan dari komunitas muslim terhadap Al-Quran telah meningkat. Saat ini, begitu banyak aplikasi bacaan/hafalan Quran, terutama di platform mobile, namun kurang mempertimbangkan preferensi pengguna. Penelitian ini mengusulkan perancangan antarmuka sistem informasi hafalan Al-Quran sesuai preferensi pengguna berbasis web.

Penelitian serupa diusung oleh [5] menggunakan metode ISO/IEC 9126-1 dengan variabel pengukuran usability, functionality dan reliability studi kasus di Mungkid, Jawa Tengah. Penelitian tersebut belum menyentuh sisi user preference dalam design antar muka berbasis human centered modelling and design. Sehingga penelitian ini mengembangkan sisi user preference dengan mengambil tempat penelitian (studi kasus) di UIN Sunan Ampel Surabaya di UPTQ (Unit Pengembangan Tahfidzul Quran). Metode pengujian yang digunakan adalah metode kombinasi antara heuristik evaluation dan ISO 9241-1, sehingga hasilnya bisa lebih presisi. Adapun UPTQ sendiri adalah salah satu unit kegiatan kemahasiswaan di UIN Sunan Ampel Surabaya yang menampung semua kegiatan mulai dari pembacaan Quran hingga wisuda menjadi Tahfidz. Proses bisnis di UPTQ mulai membimbing dalam pembacaan, merekam jejak hafalan anggota, merekam absensi anggota, memberikan pemeriksa yang berpengalaman dalam bidang ini untuk menyampaikan anggota yang sudah memenuhi syarat sebagai pembacanya, dst. Sistem informasi hafalan Al-Quran diharapkan bisa mempermudah/membuat 
kemajuan pada produktivitas proses bisnis yang ada di UPTQ.

\section{LITERATUR}

\subsection{Human Centered Modelling and Design}

Secara historis, pengembangan sistem komputer lebih mengumatakan sisi teknologi. Teknolog percaya bahwa "pengguna dapat menyesuaikan" dengan apapun yang mereka bangun. Akibatnya, mereka biasanya mengandalkan pengajaran, pelatihan, dan latihan dengan antarmuka untuk mendorong pengguna berinteraksi dengan cara yang sesuai dengan kemampuan pemrosesan sistem. Human centered design mendukung pendekatan yang lebih menjanjikan dan bertahan lama untuk memodelkan perilaku alami pengguna, termasuk kendala pada kemampuan mereka untuk hadir, belajar, dan melakukan, sehingga antarmuka dapat dirancang yang lebih intuitif, mudah dipelajari. dan lebih bebas dari kesalahan kinerja. Dampak potensial dari pendekatan ini adalah peningkatan substansial dalam kelangsungan komersial sistem generasi berikutnya untuk berbagai aplikasi dunia nyata [6]. Perkembangan yang berpusat pada pengguna melibatkan banyak hal, bagaimana mengenali pengguna dan tugasnya, yang selanjutnya diterjemahkan dalam desain. Terdapat beberapa teknik pengumpulan data yang dapat digunakan untuk mengumpulkan informasi, termasuk (a)pengamatan naturalistik. Salah satu metode khusus yang telah berhasil digunakan untuk pengamatan naturalistik adalah etnografi. Ini juga telah digunakan dalam keberhasilan dalam pengembangan produk. Aspek lain dari pengembangan terpusat pengguna adalah (b)keterlibatan pengguna dalam proses pengembangan. Ada berbagai tingkat keterlibatan, salah satunya adalah melalui studi evaluasi. Dan (c) pengguna untuk berkontribusi secara aktif pada desain itu sendiri untuk menjadi codesigners. Teknik ini telah dikembangkan yang melibatkan pengguna secara aktif dan produktif dalam desain [7], [8], [9].

\subsection{Heuristic Evaluation}

Evaluasi Heuristik adalah panduan, prinsip umum, atau aturan yang dapat menuntun keputusan rancangan atau digunakan untuk mengkritik suatu keputusan yang sudah diambil [10], [11], [12]. Evaluasi Heuristik diusulkan oleh Nielsen dan Molich melalui sekumpulan kriteria usability atau heuristic yang diidentifikasi untuk memperbaiki perancangan secara efektif. Dalam melakukan evaluasi, terdapat sepuluh prinsip dalam Evaluasi Heuristik [11] sebagaimana pada ditunjukkan pada Tabel 1 .

Tabel 1 Term of Heuristic Evaluation

\begin{tabular}{|c|c|}
\hline Term & Definition \\
\hline $\begin{array}{l}\text { Visibility of } \\
\text { system status } \\
\text { (feedback) }\end{array}$ & $\begin{array}{l}\text { Sistem harus selalu } \\
\text { menginformasikan pada } \\
\text { pengguna apa yang sedang } \\
\text { terjadi, melalui pesan yang baik } \\
\text { dan waktu yang sesuai. }\end{array}$ \\
\hline $\begin{array}{l}\text { Match between } \\
\text { system and the } \\
\text { real world }\end{array}$ & $\begin{array}{l}\text { Sistem harus berbicara sesuai } \\
\text { dengan bahasa penggunanya, } \\
\text { menggunakan kata, kalimat, dan } \\
\text { konsep yang biasa digunakan } \\
\text { oleh pengguna. }\end{array}$ \\
\hline $\begin{array}{l}\text { Use Control } \\
\text { and Freedom }\end{array}$ & $\begin{array}{l}\text { Pengguna harus dapat secara } \\
\text { bebas memilih dan melakukan } \\
\text { pekerjaan (sesuai kebutuhan). } \\
\text { Pengguna harus dapat } \\
\text { mengambil keputusannya } \\
\text { sendiri (dengan informasi yang } \\
\text { jelas) berkaitan dengan } \\
\text { pekerjaan yang sedang/akan } \\
\text { dilakukan. Sistem harus } \\
\text { memiliki kemampuan untuk } \\
\text { undo dan redo }\end{array}$ \\
\hline $\begin{array}{l}\text { Consistency } \\
\text { and Standards }\end{array}$ & $\begin{array}{l}\text { Pengguna tidak perlu } \\
\text { mempertanyakan lagi mengenai } \\
\text { perbedaan pemahaman pada } \\
\text { sebuah kata dan kalimat, situasi } \\
\text { dan aksi. Semua harus sudah } \\
\text { mengikuti standar yang ada. }\end{array}$ \\
\hline $\begin{array}{l}\text { Error } \\
\text { Prevention }\end{array}$ & $\begin{array}{l}\text { Merancang sistem yang } \\
\text { mencegah terjadinya kesalahan } \\
\text { lebih baik daripada merancang } \\
\text { pesan kesalahan yang baik. }\end{array}$ \\
\hline $\begin{array}{l}\text { Recognation } \\
\text { Rather } \\
\text { than Recall }\end{array}$ & $\begin{array}{l}\text { Pengguna tidak perlu } \\
\text { mempertanyakan lagi mengenai } \\
\text { perbedaan pemahaman pada } \\
\text { sebuah kata dan kalimat, situasi } \\
\text { dan aksi. Semua harus sudah } \\
\text { mengikuti standar yang ada. }\end{array}$ \\
\hline $\begin{array}{l}\text { Flexibility and } \\
\text { Efficient of Use }\end{array}$ & $\begin{array}{l}\text { Bagaimana membuat sebuah } \\
\text { sistem yang mengakomodasi } \\
\text { pengguna yang sudah ahli dan } \\
\text { pengguna yang masih pemula. } \\
\text { Berikan alternatif untuk } \\
\text { pengguna yang "berbeda" dari } \\
\text { pengguna biasa (secara fisik, } \\
\text { budaya, bahasa, dll). }\end{array}$ \\
\hline
\end{tabular}


Vol. 03, No. 01, Agustus 2017, 9-14

\begin{tabular}{|l|l|}
\hline $\begin{array}{l}\text { Aesthetic and } \\
\text { Minimalist } \\
\text { Design }\end{array}$ & $\begin{array}{l}\text { Sistem hanya menghasilkan } \\
\text { informasi yang relevan, } \\
\text { informasi yang tidak relevan } \\
\text { mengurangi visibilitas dan } \\
\text { usability dari sistem }\end{array}$ \\
\hline $\begin{array}{l}\text { Help users } \\
\text { recognize, } \\
\text { dialogue, and } \\
\text { recovers from } \\
\text { errors }\end{array}$ & $\begin{array}{l}\text { Pembuatan objek, aksi dan } \\
\text { pilihan harus jelas terlihat. } \\
\text { Pengguna tidak harus } \\
\text { mengingat-ingat informasi dari } \\
\text { satu halaman ke halaman lain. } \\
\text { Instruksi dan informasi pada } \\
\text { sistem haras mudah diakses dan } \\
\text { jelas terlihat pada saat } \\
\text { dibutuhkan. }\end{array}$ \\
\hline $\begin{array}{l}\text { Help } \\
\text { and }\end{array}$ & $\begin{array}{l}\text { Sistem harus memiliki } \\
\text { dokumentasi yang relevan dan } \\
\text { fitur help yang baik, sehingga } \\
\text { pengguna dapat mempelajari } \\
\text { segala sesuatu yang terkait } \\
\text { dengan sistem. }\end{array}$ \\
\hline
\end{tabular}

\section{METODE PENELITIAN}

Metode penelitian yang digunakan adalah Research and Development's method (R\&D) level 1 [13] dengan langkah-langkah penelitian ditunjukkan pada Gambar 1 dibawah ini :

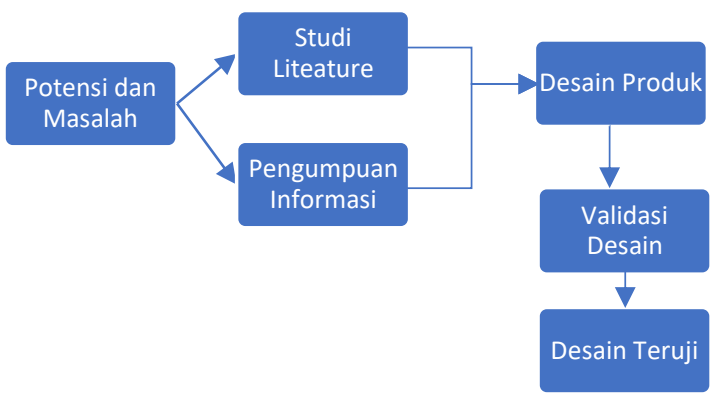

Gambar 1 Langkah-langkah Penelitian

Sedangkan model pengembangan perangkat lunak menggunakan metode prototyping. Metode prototyping cocok digunakan saat calon pengguna memberikan kebutuhan aplikasi secara umum tetapi tidak memberikan detail kebutuhan input, process, dan output dari aplikasi (Pressman, 2010: 30). Model ini dipilih karena pengelola UPTQ masih mencari bentuk yang ideal.

Model pengembangan prototyping terdiri dari tiga tahap yaitu Listening to customer, Build or revise mock-up dan Customer test drives mockup (lihat Gambar 2). Ketiga tahap tersebut diulang-ulang sampai didapatkan hasil yang sesuai dengan spesifikasi sistem yang dibutuhkan. Sistem kemudian diuji aspek desain interface-nya menggunakan metode heuristic dan aspek usability-nya menggunakan standar ISO 9241-11 untuk mengetahui tingkat efektifitas, efisiensi dan kepuasan dari sistem yang telah dibuat.

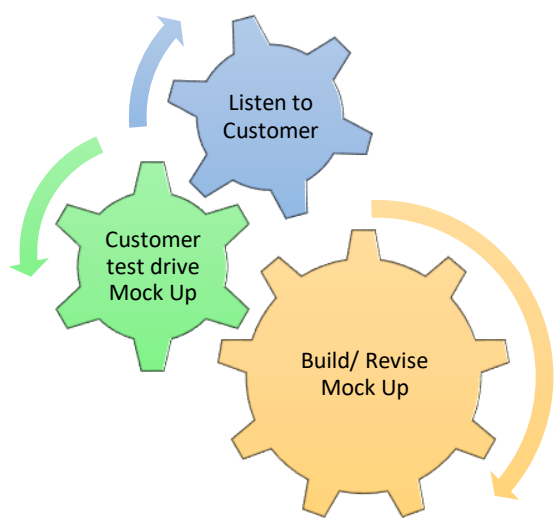

Gambar 2 Prosedur Pengembangan Software

Prosedur Pengembangan Perangkat Lunak yang digunakan dalam penelitian ini adalah :

1. Tahap listen to customer digunakan untuk mengidentifikasi kebutuhan pengguna. Pada tahapan ini dilakukan studi lapangan, studi dokumen dan wawancara pada calon pengguna.

2. Tahap Build/Revise Mock Up, prototipe dikembangkan berdasarkan hasil identifikasi kebutuhan pengguna.

3. Tahap customer test drive Mock Up yaitu tahapan calon pengguna mencoba hasil prototipe dan memberikan hasil evaluasi dari prototipe yang dikembangkan. Teknik evaluasi yang digunakan yaitu Heuristik Evaluation.

Ketiga tahapan diulang sampai perangkat lunak siap untuk digunakan calon pengguna. Setelah pengembangan selesai, dilakukan pengujian kelayakan menggunakan standar ISO 9241-11

\subsection{Data dan Instrumen}

Pengujian desain interface dilakukan dengan menggunakan kuesioner sesuai intrumen heuristic evaluation dengan skala likert. Pengujian aspek usability (ISO 9241-11) dilakukan dengan menguji efektivitas, efisiensi, dan kepuasan terhadap aplikasi yang dibuat. Adapun subyek penelitian yang menjadi sumber data dalam penelitian ini adalah anggota UPTQ, musrif/ah, musrif/ah alumni, dan BPH (Badan Pengurus Harian) yang berjumlah 75 responden

\subsection{Teknik Analisis Data}

Analisis aspek desain interface menggunakan analisis deskripsi, Analisis aspek usabilitas yang dilihat dari tingkat efektivitas, 
efisiensi dan kepuasan merujuk pada metrik ISO 9241 sebagaimana tertera dalam Gambar 3.

\begin{tabular}{llll} 
Usability objective & $\begin{array}{l}\text { Effectiveness } \\
\text { measures }\end{array}$ & $\begin{array}{l}\text { Efficiency } \\
\text { measures }\end{array}$ & $\begin{array}{l}\text { Satis } \\
\text { meas }\end{array}$ \\
Suitability for the task & $\begin{array}{l}\text { Percentage of goals } \\
\text { achieved }\end{array}$ & $\begin{array}{l}\text { Time to complete a } \\
\text { task }\end{array}$ & $\begin{array}{l}\text { Ratir } \\
\text { satisi }\end{array}$ \\
$\begin{array}{l}\text { Appropriate for } \\
\text { trained users }\end{array}$ & $\begin{array}{l}\text { Number of power } \\
\text { features used }\end{array}$ & $\begin{array}{l}\text { Relative efficiency } \\
\text { compared with an } \\
\text { expert user }\end{array}$ & $\begin{array}{l}\text { Ratir } \\
\text { satisi }\end{array}$ \\
Learnability & $\begin{array}{l}\text { Percentage of } \\
\text { functions learned }\end{array}$ & $\begin{array}{l}\text { Time to learn } \\
\text { criterion }\end{array}$ & $\begin{array}{l}\text { Ratir } \\
\text { ease }\end{array}$ \\
Error tolerance & $\begin{array}{l}\text { Percentage of } \\
\text { errors corrected }\end{array}$ & $\begin{array}{l}\text { Time spent on } \\
\text { correcting errors }\end{array}$ & Ratir \\
& errol \\
& successfully & & \\
\hline
\end{tabular}

Gambar 3 Matrik ISO 9241 [2]

Bahwa tingkat efektifitas dihitung dari :

a. percentage of goals achieved

b. Number of power features used

c. Percentage of functions learned

d. Percentage of errors corrected successfully

Tingkat efisiensi dihitung dari :

a. Lamanya waktu user menyelesaikan task

b. Perbandingan penyelsaian task untuk expert user

c. Time to learn

d. Time spent on correcting errors

Tingkat Kepuasan dihitung dari:

a. Rating scale for satisfaction

b. Rating scale for satisfaction with power feature

c. Rating scale for ease of learning

d. Rating scale for handling error

Selanjutnya penghitungan aspek usability untuk menguji tingkat kelayakan $(t k)$ system dihitung melalui rumus :

$$
t k=\frac{\text { skor hasil penelitian }}{\text { skor nilai yang diharapkan }} \times 100 \%
$$

\section{HASIL DAN PEMBAHASAN}

Berdasarkan penelitian yang telah dilakukan mengunakan model pengembangan prototyping, didapatkan hasil berikut :

1. Tahapan listen to customer, bahwa perangkat lunak yang dibutuhkan olen pengguna memiliki user role : admin, musrif/ah dan anggota

2. Tahap Build/Revise Mock Up, bahwa perancangan dan implementasi system yang dibangun menggunakan model perancangan konvensional. Perancangan Data Flow Diagram ditunjukkan pada Gambar 4. Adapun proses bisnis yang ada dalam perangkat lunak ini :
a. Proses login
b. Proses pengelolaan data masuk
c. Proses rekam jejak hafalan/pengulangan
d. Proses pemblokiran data
e. Proses pembuatan transkrip

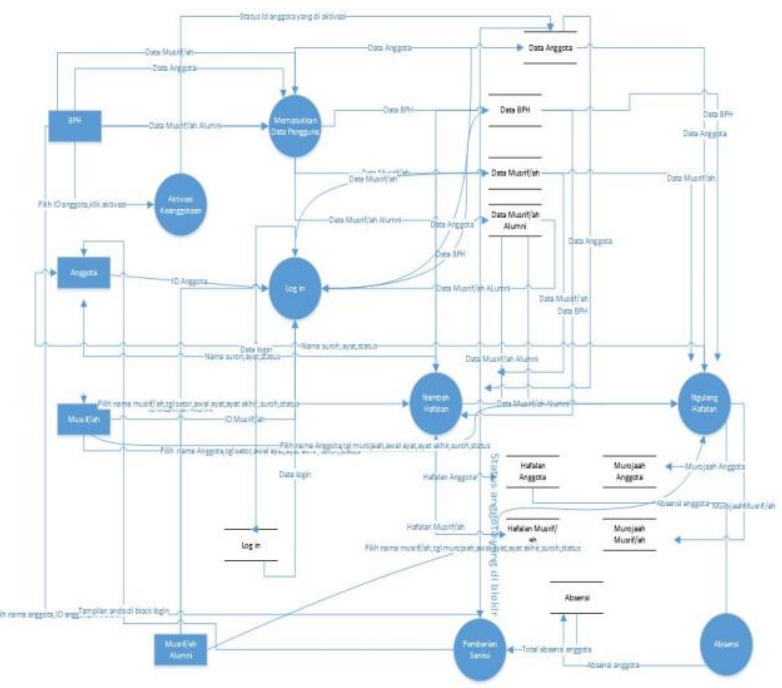

Gambar 4 DFD Level 1

3. Tahapan customer test drive Mock Up, dilakukan pengujian/evaluasi terhadap desain interface dari prototipe yang dikembangkan. Dengan menggunakan metode heuristic Evaluation, rangkuman pengujian perangkat lunak menghasilkan sebagai berikut (Lihat Tabel 2) :

Tabel 2 Rangkuman Hasil Evaluasi Heuristic

\begin{tabular}{|l|l|}
\hline \multicolumn{1}{|c|}{$\begin{array}{c}\text { Term of } \\
\text { Heuristic }\end{array}$} & \multicolumn{1}{c|}{ Recommendations } \\
\hline $\begin{array}{l}\text { Visibility Of } \\
\text { System Status / } \\
\text { Feedback }\end{array}$ & $\begin{array}{l}\text { Sudah cukup memadai namun } \\
\text { kurang di beberapa bagian } \\
\text { seperti saat search di tab sanksi } \\
\text { kemudian mencari anggota yang } \\
\text { terkena blokir. Saat nama tidak } \\
\text { terdaftar dalam daftar sanksi, } \\
\text { seharusnya ada tulisan "Nama } \\
\text { yang anda cari tidak terdaftar" }\end{array}$ \\
\hline $\begin{array}{l}\text { Match } \\
\text { between } \\
\text { system and the } \\
\text { real world } \\
\text { (metapor) }\end{array}$ & $\begin{array}{l}\text { Banyak menu yang sudah sesuai } \\
\text { dengan fungsinya kecuali saat } \\
\text { menambah hafalan, alangkah } \\
\text { baiknya jika menggunakan ikon } \\
\text { add/+ }\end{array}$ \\
\hline $\begin{array}{l}\text { User control } \\
\text { and freedom } \\
\text { (navigation) }\end{array}$ & $\begin{array}{l}\text { Alangkah lebih baiknya jika ada } \\
\text { fitur undo/redo, tidak ada show } \\
\text { confirm dialog saat klik tombol } \\
\text { keluar }\end{array}$ \\
\hline
\end{tabular}




\section{SYSTEMIC}

Vol. 03, No. 01, Agustus 2017, 9-14

\begin{tabular}{|c|c|}
\hline $\begin{array}{l}\text { ncy } \\
\text { dards }\end{array}$ & $\begin{array}{l}\text { Kurang adanya kekonsistenan } \\
\text { pada lambang UPTQ pada setiap } \\
\text { halam yang ditampilkan }\end{array}$ \\
\hline $\begin{array}{l}\text { Error } \\
\text { Prevention }\end{array}$ & $\begin{array}{l}\text { Cukup memadai karena setiap } \\
\text { inputan yang dinilai penting akan } \\
\text { menampilkan pemberitahuan } \\
\text { saat akan ada kesalahan. }\end{array}$ \\
\hline $\begin{array}{l}\text { Recognition } \\
\text { rather than } \\
\text { recall } \\
\text { (memory) }\end{array}$ & 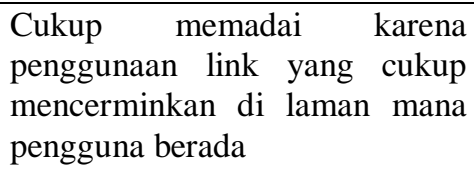 \\
\hline $\begin{array}{l}\text { Flexibility and } \\
\text { efficiency of } \\
\text { use }\end{array}$ & $\begin{array}{l}\text { Cukup flexible karena didukung } \\
\text { oleh perancangan database yang } \\
\text { banyak menggunakan trigger di } \\
\text { dalamnya. Kecuali saat } \\
\text { pemberian sanksi/pemblokiran } \\
\text { login anggota, hal ini dilakukan } \\
\text { secara manual dan tidak ada } \\
\text { perhitungan khusus dalam } \\
\text { programnya }\end{array}$ \\
\hline $\begin{array}{l}\text { Aesthetic and } \\
\text { minimalist } \\
\text { design }\end{array}$ & $\begin{array}{l}\text { Cukup memadai karena } \\
\text { informasi dalam pop up hanya } \\
\text { menampilkan informasi yang } \\
\text { dibutuhkan/ simple. }\end{array}$ \\
\hline $\begin{array}{l}\text { Help users } \\
\text { recognize, } \\
\text { dialogue, and } \\
\text { recovers from } \\
\text { errors }\end{array}$ & $\begin{array}{l}\text { Perlu adanya penempatan yang } \\
\text { tepat bagi anggota UPTQ supaya } \\
\text { yang bukan anggota memahami } \\
\text { bagaimana dia bisa mengikuti } \\
\text { hafalan di UPTQ tanpa harus } \\
\text { menjadi anggota }\end{array}$ \\
\hline $\begin{array}{l}\text { Help and } \\
\text { documentation }\end{array}$ & AQ \\
\hline
\end{tabular}

Pengembangan kedepan yaitu dengan mempertimbangkan kompatibilitas terhadap platform mobile sehingga efektifitas dan efisiensi bisa lebih meningkat dan perlunya penggunaan metode pengujian yang lebih komplek.

\section{DAFTAR PUSTAKA}

[1] A. Read, A. Tarrell, and A. Fruhling, "Exploring user preference for the dashboard menu design," Proc. 42nd Annu. Hawaii Int. Conf. Syst. Sci. HICSS, pp. 1-10, 2009.

[2] A. Dix, "Human-computer interaction, foundations and new paradigms," J. Vis. Lang. Comput., 2016.

[3] D. A. Norman, The Design of Everyday Things, vol. 16, no. 4. 2013.

[4] J. Johnson, Designing with the mind in mind: simple guide to understanding user interface design rules. 2010.

[5] S. Berbasis et al., "PENGEMBANGAN SISTEM INFORMASI TAHSIN TAHFIDZ AL QUR' AN," pp. 1-7.

[6] S. Oviatt, "Human-centered design meets cognitive load theory," Proc. 14th Annu. ACM Int. Conf. Multimed. - Multimed. '06, p. 871, 2006.

[7] H. Sharp, Y. Rogers, and J. Preece, "Interaction design: beyond humancomputer interaction," Book, vol. 11, p. 773, 2007.

[8] K. Li, A. Tiwari, J. Alcock, and P. Bermell-Garcia, "Categorisation of visualisation methods to support the design of Human-Computer Interaction Systems," Appl. Ergon., vol. 55, pp. 85107, 2016.

"Baik" yaitu sebesar $82,1 \%$. Hasil pengujian tingkat efisiensi tergolong "Baik" yaitu sebesar $81,87 \%$ dan tingkat kepuasan terhadap sistem "Cukup Baik" yaitu sebesar 78,9\%. Dengan demikian diperoleh uji kelayakan aspek usability dari sistem sebesar $80,22 \%$ dan dinyatakan layak untuk digunakan/diimplementasikan di UPTQ UIN Sunan Ampel Surabaya.

\section{SIMPULAN}

Hasil penelitian ini masih perlu dikembangkan sekalipun sudah teruji dan dinyatakan layak dengan prosentase $80,22 \%$. Tingkat efektifitas tergolong "Baik" yaitu sebesar 82,1\%, tingkat efisiensi tergolong "Baik" yaitu sebesar 81,87\% dan tingkat kepuasan terhadap sistem "Cukup Baik“ yaitu sebesar 78,9\% .Dengan demikian system informasi yang dikembangkan ini bisa memaksimalkan/ mengoptimalkan proses bisnis di UPTQ UIN Sunan Ampel Surabaya.

[9] T. Issa and P. Isaias, "Sustainable design: Hci, usability and environmental concerns," Sustain. Des. Hci, Usability Environ. Concerns, pp. i-iii, 2015.

[10] M. Ispani, "REVIEW DESAIN INTERFACE APLIKASI SOPPPOS MENGGUNAKAN," vol. 6, no. 1, pp. 95-100, 2015.

[11] R. Molich and D.- Ballerup, "HEURISTIC EVALUATION," no. April, pp. 249-256, 1990.

[12] R. Firmansyah, "EVALUASI HEURISTIK PADA DESAIN INTERFACE APLIKASI MY INDIHOME," pp. 66-73, 2016.

[13] Sugiyono, "Metode Penelitian \& Pengembangan Research and Development", 2016. 
